Pesq. Vet. Bras. 36(10):930-934, outubro 2016

DOI: $10.1590 /$ S0100-736X2016001000002

\title{
Occurrence of anti-Brucella antibodies in intensive pig farming and in non-technified pig herds ${ }^{1}$
}

\author{
Paloma Ricardo², Luís G. Oliveira ${ }^{2 *}$, Thaís G. Baraldi ${ }^{3}$,Marina L. Mechler ${ }^{3}$, Henrique \\ M.S. Almeida ${ }^{3}$, Glaucenyra C.P. da Silva ${ }^{3}$, Igor R.H. Gatto ${ }^{3}$ and Luis A. Mathias ${ }^{2}$
}

\begin{abstract}
Ricardo P., Oliveira L.G., Baraldi T.G., Mechler M.L., Almeida H.M.S., Silva G.C.P., Gatto I.R.H. \& Mathias L.A. 2016. Occurrence of anti-Brucella antibodies in intensive pig farming and in non-technified pig herds. Pesquisa Veterinária Brasileira 36(10):930-934. Faculdade de Ciências Agrárias e Veterinárias, Universidade Estadual Paulista, Via de Acesso Prof. Paulo Donato Castellane s/n, Jaboticabal, SP 14884-900, Brazil. E-mail: luis.guilherme@fcav.unesp.br

The aim of this study was to determine the occurrence of antibodies anti-Brucella in 1,940 swine blood samples. Out of the 1,940 sera samples, 1,594 were from 30 intensive pig farming from seven different states, collected during the slaughtering of animals, and 346 samples from 56 non-technified (subsistence) pig herds from Jaboticabal region, São Paulo State, Brazil. All samples were tested by Buffered Plate Acidified Antigen (BPAA) and considered positive in case of agglutination. If positive, the samples were tested by Complement Fixation Reaction (CFR) as a confirmatory test. Out of the 1,594, two were positive for BPAA but negative for CFR, so the occurrence was $0 \%$. Among the 346 samples, two were positive for BPAA but only one was positive in the confirmatory test, whith a titer of 1:8. Thus, the occurrence was $0.29 \%$, an important result to demonstrate the improvement of the sanitary status of Brazilian non-technified pig herds, despite the low conditions of production.
\end{abstract}

INDEX TERMS: Anti-Brucella antibodies, pig farming, brucellosis, swine, serology, slaughterhouse, zoonosis.

RESUMO.- [Ocorrência de anticorpos anti-Brucella em suínos de granjas comercias e de criações de subsistência.] 0 presente estudo foi realizado com o objetivo de se determinar a ocorrência de anticorpos anti-Brucella spp. em 1.940 amostras de sangue de suínos, das quais 1.594 amostras eram de 30 granjas comerciais, de sete diferentes Estados, coletadas durante o abate dos animais, e 346 amostras de 56 criações de subsistência da região de Jaboticabal, Estado de São Paulo, Brasil. Todas as amostras foram submetidas ao teste do Antígeno Acidificado Tamponado (AAT) e consideradas positivas caso ocorresse aglutinação. Quando positivas, as amostras eram submetidas ao teste de Reação de Fixação de Complemento

\footnotetext{
${ }^{1}$ Received on December 9, 2015.

Accepted for publication on July 1, 2016.

${ }^{2}$ Faculdade de Ciências Agrárias e Veterinárias, Universidade Estadual Paulista (Unesp), Via de Acesso Prof. Paulo Donato Castellane s/n, Jaboticabal, SP 14884-900, Brazil. *Corresponding author: luis.guilherme@ fcav.unesp.br

${ }^{3}$ Curso de Medicina Veterinária, Unesp, Via de Acesso Prof. Paulo Donato Castellane s/n, Jaboticabal, SP 14884-900, Brazil.
}

(RFC) como teste confirmatório. Dentre as 1.594 amostras de suínos de granjas comerciais, duas se mostraram sensíveis ao AAT, porém, quando foram submetidas à RFC, ambas apresentaram reação negativa, levando a uma porcentagem de ocorrência de $0 \%$. Já entre as 346 amostras de criações de subsistência, duas foram positivas ao AAT, sendo que apenas uma apresentou reação positiva no teste confirmatório, cujo título foi de 1:8. Desta forma, a ocorrência foi de $0,29 \%$, resultado importante para demonstrar a melhoria do status sanitário dos rebanhos de subsistência brasileiros, apesar das condições precárias em que vivem.

TERMOS DE INDEXAÇÃO: Anticorpos anti-Brucella, brucelose, suínos, sorologia, abatedouro, zoonose.

\section{INTRODUCTION}

Brazil is the fourth largest producer and exporter of pork in the world, being an important activity for Brazilian economy (ABIPECS 2014). In a country with high production and consumption, zoonosis in pigs deserves careful attention. For this reason, Brucellosis has high importance 
to animal production and public health. Brucellosis is an anthropozoonosis caused by bacteria and, regarding pigs, Brucella suis is the main agent. The disease was first reported in humans in 1887, by the doctor David Bruce, by isolating the bacteria from spleen samples lifted in autopsies of militaries who died by this disease. The occurrence in animals was only characterized years later (Freitas et al. 2001, Gomes 2013).

There are five known Brucella suis corresponding biovars, namely 1, 2, 3, 4 and 5 . The biovars 1,2 and 3 are known for affecting pigs, whereas 1 and 3 are the most pathogenic for humans. The occurrence in humans is related to regions where biovars 1 and 3 are endemic in domestic pigs and wild swine (Olsen et al. 2012). The infection by $B$. suis is the second most prevalent regarding the Brucella genus in Brazil, being Brucella abortus the first one, and also the second most pathogenic in the world, coming after Brucella mellitensis (OIE 2009, Jesus et al. 2010).

In addition, brucellosis is an occupational disease, since veterinarians, slaughterhouse workers and farm workers can become infected by handling aborted fetuses and remains, manipulating infected animal meat and by handling sick animals during delivery. The porcine is the main source of infection for humans since there are no reported cases of B. melitensis in Brazil (Matos et al. 2004). The prevalence of this disease in swine production showed a sharp decline due to the management and husbandry improvements, although sporadic outbreaks can still occur even in intensive pig farming (Mathias 2008). However, it is a remained problem in non-technified pig herds (Plumb et al. 2013).

In non-technified pig herds, where several species are reared close to each other, studies indicate an influence of cattle herd in the occurrence of swine brucellosis, by brucellosis cross-transmission between species, with B. abortus affecting pigs and $B$. suis infecting cattle herds (Leite et al. 2014). The transmission occurs by contaminated food and water, vulvar discharge, abortion material as fetuses, stillbirths and placenta. In males, the main clinical sign is orchitis, however other genital organs can be infected. Bacterial isolation in semen from asymptomatic animals is possible, characterizing another way of transmission (Jesus et al. 2010). There is no treatment recommendation and no available vaccines against swine brucellosis. The control is based on the diagnosis of infected animals, isolation and slaughter of the infected ones (Nicoletti 2013).

The clandestine pig slaughtering still occurs along the country, representing a high risk to public health, exposing people to infectious agents such as B. suis, by the consumption of non-inspected meat, , by the contact with sick animals and by environment contamination. However, despite the facts, these slaughterhouses do not receive the necessary attention (Rosa et al. 2012). Therefore, management and biosecurity are extremely important issues in maintaining a healthy herd (Filippsen et al. 2001). Considering the importance of the disease for pork production, this study aimed to determine the occurrence of antibodies anti-Brucella spp in 1940 pig blood sample from intensive pig farming and non-technified pig herds.

\section{MATERIALS AND METHODS}

Among the 1,940 pig blood samples collected, 1,594 were taken from bleeding procedure at slaughterhouses in the region of Jaboticabal, São Paulo, coming from seven different states (RS, SC , PR, $\mathrm{SP}, \mathrm{MT}, \mathrm{MS}, \mathrm{GO})$, in a total of 30 intensive pig farming, as seen in Figure 1 and Table 1 . The other 346 blood samples were from 56

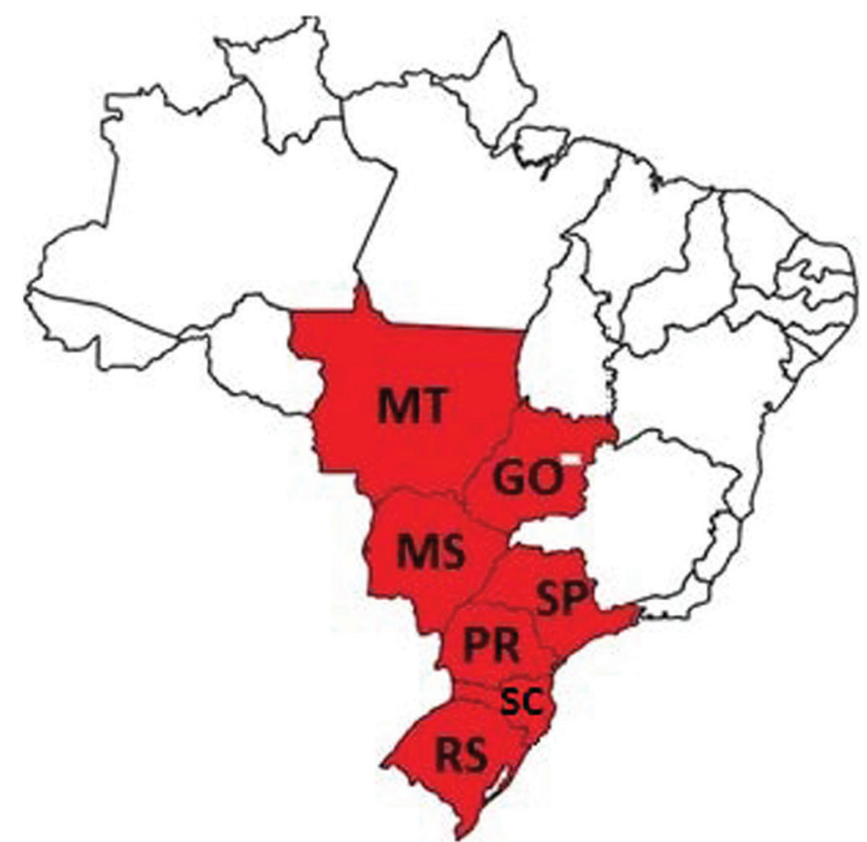

Fig.1. Areas in red represent the states in which are located the intensive pig farms sampled for analysis.

Table 1. Number of samples per batch and their respective cities of origin

\begin{tabular}{lcc}
\hline City/State & Batches & Samples \\
\hline Siqueira Campos/PR & 001 & 255 \\
Rodeio Bonito/RS & 002 & 98 \\
Siqueira Campos/PR & 003 & 104 \\
Guariba/SP & 004 & 49 \\
Cristais Paulista/SP & 005 & 16 \\
Colina/SP & 006 & 120 \\
Concórdia/SC & 007 & 104 \\
Rio Verde/GO & 008 & 61 \\
Jaboticabal/SP & 009 & 64 \\
Jaboticabal/SP & 010 & 09 \\
Saudades/SC & 011 & 128 \\
Vicentina/MS & 012 & 50 \\
Laranjeiras do Sul/PR & 013 & 30 \\
Campo Grande/MS & 014 & 30 \\
Nova Erechim/SC & 015 & 30 \\
Águas Frias/SC & 016 & 30 \\
Ipuã/SP & 017 & 31 \\
Dourados/MS & 018 & 30 \\
Iomerê/SC & 019 & 30 \\
Águas Frias/SC & 020 & 30 \\
Primavera do Leste/MT & 021 & 30 \\
Pinhalzinho/SC & 022 & 30 \\
União do Oeste/SC & 023 & 30 \\
Salto Veloso/SC & 024 & 30 \\
Rio Verde/GO & 025 & 30 \\
Pinhalzinho/SC & 026 & 27 \\
Espigão Alto do Iguaçu/PR & 027 & 29 \\
Saudades/SC & 028 & 29 \\
Chapecó/SC & 029 & 30 \\
Ponta Porã/MS & 030 & \\
TOTAL & - &
\end{tabular}






Fig.2. Map representing the region of Jaboticabal/SP and the distribution of the non-technified pig herds sampled, in this study, marked with a cross.

non-technified pig herds from the region of Jaboticabal, state of São Paulo, showed in Figure 2, and were collected by jugular vein puncture, using evacuated tubes without additive.

The samples were individually identified and delivered to the laboratory, where they were processed. Serum was obtained by centrifugation for $15 \mathrm{~min}$ at $3,500 \mathrm{xg}$ and stored at $-20^{\circ} \mathrm{C}$ until subsequent analysis. The sample analysis was submitted to BPAA test, confirmed by CFR test, and performed in the Laboratory of Diagnostic of Leptospirosis and Brucellosis, placed in the Department of Preventive Veterinary Medicine and Animal Reproduction of FCAV/Unesp.

The BPAA test was carried out following the rules of the technical manual of the National Program for Control and Eradication of Animal Brucellosis and Tuberculosis. The method consists in homogenization of the tested sera and antigen (Brucella abortus $1119 / 3$ sample at a concentration of $8.0 \%$ of cell volume, flushed with Rose Bengal, pH 3.65) for up to four minutes, observing the presence or not of agglutination lumps, resulting positive or negative, respectively.

The positive samples were submitted to the CFR test using incubation at $37^{\circ} \mathrm{C}$ in both stages of the reaction, the complement was diluted to contain 5 hemolytic units $50 \%$ as recommended by Alton et al. (1988). As antigen, we used the suspension of $B$. abortus sample 1119/3 inactivated by heat, and, as complement, guinea pig serum was used.

It was considered positive the serum with at least $12.5 \%$ of complement fixation from 1:4 dilutions. Positive samples in CFR were used to calculate the percentage of occurrence, based on the total number of samples. This study was approved by the local Ethics Commission (São Paulo State University, FCAV-Jaboticabal, Brazil: Permit Number 06701/2014).

\section{RESULTS}

The 1,940 swine sera samples collected for this seroprevalence study were characterized according to the animal origin, regarding the pig rearing-systems. In the non-technified pig herds, two samples from the same farm at Pradópolis city were positive in the BPAA test. However only one serum was positive for antibodies anti-Brucella spp. with titer of 1:8 in CFR test with the percentage of occurrence being $0.29 \%$.

In relation to the intensive pig farming, regarding the samples from slaughterhouses, two were positive at BPAA test, belonging to the batches 25 and 26 (Table 1), from far$\mathrm{ms}$ in Rio Verde (GO) and Pinhalzinho (SC), respectively. In the confirmation test (CFR), however, the samples were negative for antibodies anti-Brucella spp. and the percentage of occurrence was $0 \%$.

\section{DISCUSSION}

Non-technified pig herds. The number of seropositive pigs was lower than the expected for this rearing-system, which has a deficient sanitary control. Especially in infectious diseases such as brucellosis, rates are usually higher than the observed due to the high and rapid spread in herds.

Our results were similar to the obtained by Motta et al. (2010) who sampled 320 swine farms (non-technified pig herds, without commercial feature) and 320 intensive pig farming. The seroprevalence found was of $0 \%$, in a total of 27,300 samples from 13 Brazilian states (Bahia, Espírito Santo, Goiás, Mato Grosso, Mato Grosso do Sul, Minas Gerais, Paraná, Rio de Janeiro, Rio Grande do Sul, Santa Catarina, São Paulo, Sergipe, Tocantins and the Federal District). However, the authors suggested that the lack of antibody titers was due to the unsuitability of diagnostic technique for brucellosis in swine, being necessary to reassess parameters, as possible lower cutoffs in confirmatory tests than those used for cattle and buffalo, as well as the use of more specific antigens (Motta et al. 2010).

Thus, low rates were found in this study even using CFR test instead 2-mercaptoethanol (2-ME) as mentioned by Motta et al. (2010), as both techniques are known as gold standard in cattle and buffalo brucellosis diagnosis. Another applicable explanation to the found results is the high urbanization in these areas, presenting few subsistence productions. It entails in little or none epidemiological links among animals and between species (wild and domestic ones), resulting in a non-endemic area for brucellosis, with no significant results, as shown in this study.

In addition, the low prevalence rate might be related to the implantation of programs of "Cattle Brucellosis Control and Eradication" (Brazil 2001), which are being responsible for the decrease in bovine brucellosis cases in some regions of the country. Consequently, swine brucellosis outbreaks in which the infection source comes from cattle are getting rarer, reducing the occurrence of brucellosis in swine.

Another key issue to be considered in non-technified pig herds is the possibility of contact between domestic swine and wildlife. With the establishment of regulatory programs, the increase of confined animals, and the changes in management practices in some countries and regions (Australia, USA, western and central Europe), wild boars and feral pigs have become major reservoirs for Brucella suis in these sites (Olsen et al. 2012). There is evidence suggesting that these feral pigs remain as a source of infection for domestic pigs, since several outbreaks of $B$. suis occurred in non-technified production. 
Thereby Gresham et al. (2002) showed that the prevalence of brucellosis in feral pig population in the South Carolina state increased gradually from $18 \%$ to over $40 \%$ in a decade, being this population source of several infectious diseases for domestic pigs. Between 2000 and 2004, a seroepidemiological survey on 93,107 samples from 1,997 herds in Croatia found an individual prevalence of $1 \%$ and a herd prevalence of $3.4 \%$., With the exception of two herds, almost all of the infected animals were from non-technified pig herds, which enables contact with wild animals (Cvetnić et al. 2009). In Brazil, Freitas et al. (2004) analyzed wild animals sera in South Pantanal and obtained seropositivity for Brucella spp. in queixadas samples (Tayassu pecary), demonstrating this species as a possible natural reservoir.

Intensive pig farming. The low prevalence found shows that sanitary improvements in the Brazilian pig industry are leading to a higher health status, in accordance with the standards of the main pig producing countries, which have already controlled or eradicated swine brucellosis.

The United States of America (USA), since 1989, have a national brucellosis eradication program. In a serological survey conducted in 1993, the percentage of positives was $0.5 \%$ in the national herd, compound of 1.6 million animals, whereas the seropositive animals were from small farms located in endemic areas (1999). In a research performed in Brazil, out of 910 pig sera collected from slaughterhouses in central region of the State of São Paulo, only $2.7 \%$ were reactive in the screening test, but did not react to confirmatory tests (2-ME), resulting in no positive samples (Rosa et al. 2012).

Filippsen et al. (2001) also had 0\% of positivity for brucellosis in 969 animals from Southwest of Paraná. Braga et al. (2013), in the State of Piauí, detected antibodies anti-Brucella spp. in two samples among 192, resulting in a percentage of 1.04\%. As Barthasson (2005), in 78 samples from slaughterhouses in Goiania (Goias State) and $97 \mathrm{se}-$ rum samples collected in 12 non-technified pigs herds at the city border, only $1.7 \%$ of showed positive reactions to brucellosis, and none of these were from free-range pigs. And Azevedo et al. (2012), in a seroprevalence study of 306 pigs slaughtered in a slaughterhouse in the city of Patos (Paraíba State), observed that three $(0.98 \%)$ were positive in the BPAA test and two $(0.65 \%)$ were positive in the 2-mercaptoethanol.

However, swine brucellosis still occurs in some regions of Brazil, requiring continued control and prevention. Ribeiro et al. (2001) found positive results ranging from $19.5 \%$ to $48.6 \%$, in 972 samples from five technified farms in cities of Pernambuco Forest Zone. Borges (2004) who assessed biosecurity levels on certified farms of breeding pigs in São Paulo state obtained $9 \%$ of positivity from 2,085 samples found the same situation. Leite et al. (2014) showed that $55 \%$ of the pig farms had at least one animal positive to brucellosis. In addition, Freitas et al. (2001) obtained $42.2 \%$ of reactive animals in 139 sera samples from illegal slaughterhouses.

Despite not having a specific brucellosis eradication program for swine, a governmental directive forces farm- ers, that want to transport or commercialize breeders, to have brucellosis-free herd status which need to be renewed every 6 months, by testing all animals or at least a sample (Brazil 2002). Such animal health protection measures difficult the persistence and the spread of brucellosis among intensive pig farming, which might be involved with the low quantity of positive samples, found in this study, from intensive rearing sites.

Thus, eradication and control programs for cattle brucellosis are decreasing the occurrence of this disease in ruminants, and allied with the species specialization production of intensive pig farming, are avoiding direct contact between cattle and pigs and contributing to reduce the occurrence of swine brucellosis.

\section{CONCLUSIONS}

In this study, we determined the low incidence of serological titers for Brucella spp. in intensive pig farming and non-technified pig herds, as in the first case might suggest that these results come from great improvements at the sanitary status of Brazilian Pork Industry.

Regarding the non-technified pig herds, low rates can indeed be compatible with the low incidence of brucellosis in intensive pig farming and the establishment of cattle eradication and control programs.

Acknowledgements.- The authors would like to acknowledge farm owners, the participating slaughterhouse and the laboratory staff of Preventive Veterinary Medicine's Department of São Paulo State University and Biological Institute of São Paulo State by donating reagents for the tests.

Conflict of interest statement.- The authors declare that there is no conflict of interest.

\section{REFERENCES}

ABIPECS 2014. Estatísticas. Associação Brasileira da Indústria Produtora e Exportadora de Carne Suína. Available <http://www.abipecs.org.br/ pt/estatisticas/ mundial/exportacao.html> Last access: Oct. 2, 2015.

Alton G.G., Jones L.M., Angus R.D. \& Verger J.M. 1988. Techniques for the brucellosis laboratory. Institut Nacional de la Recherche Agronomique (INRA). 190p.

Azevedo S.S., Oliveira R.M., Silva M.L.C.R., Macedo M.M.S., Santos C.S.A.B., Alves C.J. \& Higino S.S.S. 2012. Anticorpos contra brucelas lisas em suínos abatidos no semiárido da Paraíba. Arqs Inst. Biológico, São Paulo, 79(1):97-99.

Barthasson D.L. 2005. Perfil sanitário de suínos de criações extensivas do Estado de Goiás. Dissertação de Mestrado em Ciência Animal, Universidade Federal de Goiás, Goiânia. 84p.

Braga J.F.V., Teixeira M.P.F., Franklin F.L.A.A., Souza J.A.T., Silva S.M.M.S. \& Guedes R.M.C. 2013. Soroprevalência de pseudorraiva, peste suína clássica e brucelose em suínos do estado do Piauí. Arq. Bras. Med. Vet. Zootecnia 65(5):1321-1328.

Brazil 2001. Ministry of Agriculture, Livestock and Food Supply. Governmental Directive no 21, of 16th May 2001. Published in the Official Gazette on 4th July 2001, Brasília.

Brazil 2002. Ministry of Agriculture, Livestock and Food Supply. Governmental Directive no 19, of 15th February 2002. Approves the rules to be accomplished for the Certification of Swine Breeding Farms. Official Gazette, Brasília, March 1, 2002.

Borges S.R.T. 2004. Avaliação dos níveis de biossegurança das granjas de reprodutores suínos certificadas do Estado de São Paulo. Dissertação de Mestrado, Faculdade de Medicina Veterinária e Zootecnia, Universidade Estadual Paulista (Unesp), Botucatu, SP. 91f. 
Cvetnić Z., Spicić S., Toncić J., Majnarić D., Benić M., Albert D., Thiébaud M. \& Garin-Bastuji 2009. B. Brucella suis infection in domestic pigs and wild boar in Croatia. Revue Scientifique et Technique, International Office of Epizootics, 28(3):1057-1067.

Filippsen L.F., Leite D.M.G., Silva A. \& Vargas G.A. 2001. Prevalência de doenças infecciosas em rebanho de suínos criados ao ar livre na região sudoeste do Paraná, Brasil. Ciência Rural 31(2):299-302.

Freitas J.A., Galindo G.A.R., Santos E.J.C., Sarraf K.A. \& Oliveira J.P. 2001. Risco de brucelose zoonótico associado a suínos de abate clandestino. Revta Saúde Públ. 35:101-102.

Freitas T.P.T., Paes R.C.S., Keuroglian Oliveira J.M.A., Norek A., Jansen A.M. \& Herrera H. 2004. Ocorrência de microrganismos patogênicos em queixadas, catetos e porcos de vida livre no pantanal sul-matogrossense, Corumbá, MS. Anais 4o Simpósio sobre Recursos Naturais e Sócio-econômicos do Pantanal, Corumbá, MS.

Gomes M.J.P. 2013. Gênero Brucella spp. FAVET-UFRGS. Disponível em <http://www.ufrgs.br/labacvet/files/G\%C3\%AAnero\%20Brucella \%204-2013-1.pdf> Acesso em 5 oct. 2015.

Gresham C.S., Gresham C.A., Duffy M.J., Faulker C.T. \& Patton S. 2002. Increase prevalence of Brucella suis and pseudorabies virus anti-bodies in adults of an isolated feral swine in coastal South Carolina. J. Wildl. Dis. 38(3):653-656.

Jesus V.L.T., Pereira R.C.G., Flausino W., Meireles G.S., Rodrigues J.S. \& Jorge J.L.B.P. 2010. Brucelose suína no estado do Rio de Janeiro, Brasil. Revta Bras. Med. Vet. 32(2):101-104.

Leite A.I., Coelho W.A.C., Silva G.C.P., Santos R.F., Mathias L.A. \& Dutra I.S. 2014. Prevalência e fatores de risco para brucelose suína em Mossoró/ RN. Pesq. Vet. Bras. 34(6):537-541.

MacMillan A.P. 1999. Brucellosis, p.385-393. In: Straw B.E., D’Allaire S., Mengeling W.L. \& Taylor D.J. (Eds), Diseases of Swine. 8th ed. Iowa State University Press, Ames.
Mathias L.A. 2008. Brucelose animal e suas implicações em saúde pública. Biológico, São Paulo, 70(2):47-48.

Matos M.P.C., Sobestiansky J., Porto R.N.G. \& Meirinhos M.L.G. 2004. Ocorrência de anticorpos para Brucella sp. em soros de matrizes suínas de granjas que abastecem o mercado consumidor de Goiânia, Estado de Goiás, Brasil. Ciênc. Anim. Bras. 5(2):105-108.

Motta P.M.C., Fonseca J.R.A.A., Oliveira A.M., Nascimento K.F., Soares Filho P.M., Serra C.V., Jesus A.L. \& Rivetti Jr M.F. 2010. Inquérito soroepidemio-lógico para brucelose em suídeos do Brasil. Veterinária em Foco 7:141147.

Nicoletti P. 2013. Merck Veterinary Manual. Disponível em <http://www. merckvetmanual.com/mvm/reproductive_system/brucellosis_in_large_animals/brucellosis_in_pigs.html?qt=brucellosis\&alt=sh $>$ Acesso em Oct. 2, 2015.

OIE 2009. Porcine brucellosis. Terrestrial Manual, Chapter 2.8.5. Organização Mundial da Saúde Animal. Available <http://www.oie.int/fileadmin/Home/eng/Health_standards/tahm/2.08.05_PORCINE_BRUC. pdf> Last access Oct. 3, 2015.

Olsen S.C., Garin-Bastuji B., Blasco J.M., Nicola A.M. \& Samartino L. 2012. Brucellosis, p.697-708. In: Zimmerman J.J., Karriker L.A., Ramires A.R., Schwartz K.J. \& Stevenson G.W. (Eds), Diseases of Swine. 10th ed. Iowa State University Press, Ames.

Plumb G.E., Olsen S.C. \& Buttke D. 2013. Brucellosis: 'One Health' challenges and opportunities. Revue. Scientifique et Technique, International Office of Epizootics, 32(1):271-278.

Ribeiro T.C.F.S., Matos R.A., Costa A.N., Lima E.T. \& Castro Junior I.F. 2001. Inquérito soroepidemiológico da brucelose suína em granjas comerciais da Zona da Mata de Pernambuco. Ciência Animal 11(2):65-71.

Rosa D.C., Garcia K.C.O.D. \& Megid J. 2012. Seropositivity for brucellosis in pigs in slaughterhouses: soropositividade para brucelose em suínos em abatedouros. Pesq. Vet. Bras. 32(7):623-626. 